\title{
PROF. DR HAB. MYKOLAS MICHELBERTAS - PIERWSZY ZAGRANICZNY LAUREAT NAGRODY IM. JÓZEFA KOSTRZEWSKIEGO
}

W dniu 20 października 2016 r. w Instytucie Polskim w Wilnie odbyło się wręczenie Nagrody im. Józefa Kostrzewskiego prof. dr. hab. Mykolasowi Michelbertasowi (fot. 1). Laureat jest jednym z najwybitniejszych archeologów i numizmatyków litewskich przełomu XX i XXI w., emerytowanym wykładowcą Uniwersytetu Wileńskiego w Wilnie i Uniwersytetu im. Witolda Wielkiego w Kownie, członkiem Państwowej Komisji Ochrony Zabytków Republiki Litewskiej, ekspertem w sprawach polityki i strategii ochrony dziedzictwa kulturowego Republiki Litewskiej.

Nagroda im. Józefa Kostrzewskiego przyznawana jest przez Zarząd Główny Stowarzyszenia Naukowego Archeologów Polskich i Instytut Prahistorii (obecnie Archeologii) UAM za wybitne osiągnięcia badawcze w dziedzinie archeologii. Prof. dr. hab. Mykolas Michelbertas jest pierwszym obcokrajowcem, który został nagrodzony tym prestiżowym $\mathrm{w}$ polskim środowisku archeologicznym wyróżnieniem.

Dorobek naukowy Laureata w pełni uzasadnia taką decyzję kapituły nagrody. Profesor dr. hab. Mykolas Michelbertas jest bowiem autorem licznych prac naukowych poświęconych dziejom ludów bałtyjskich w okresach wpływów rzymskich oraz wędrówek ludów. Jego publikacje książkowe, takie jak:

Lietuvos archeologiniai paminklai. Lietuvos pajūrio I-VII a. kapinynai, straipsniai apie Ankštakiu, Rüdaičiu, Rüdaičiu II ir Senku kapinynus, Vilnius 1968,

Senasis geležies amžius Lietuvoje, Vilnius 1986,

Seniausia Lietuvos praeitis (archeologiniu tyrimu duomenimis), 1989,

Lietuvos numizmatikos ìvadas, Vilnius 1989,

Paragaudžio pilkapynas, Vilnius 1997,

Corpus der romischen Funde im europaischen Barbaricum. Litauen, Vilnius 2001,

Pajuosčio pilkapynas, Vilnius 2004,

Akmeniu ir Perkūniškès pilkapiai, Vilnius 2006,

Lietuvos pinigai, Vilnius 2006, 


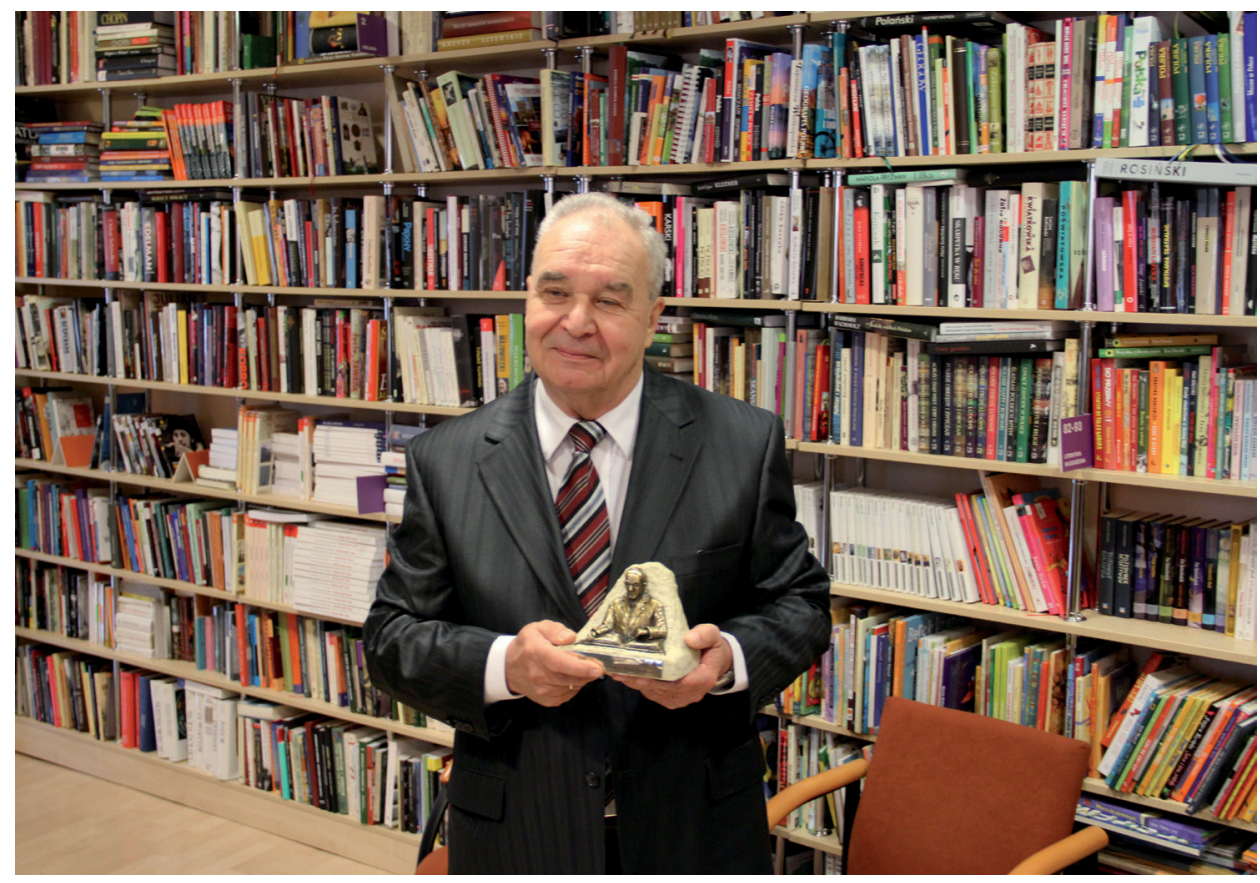

Fot. 1. Prof. dr hab. Mykolas Michelbertas - laureat Nagrody im. Józefa Kostrzewskiego (fot. Andrzej Kierulis)

Kuršiu pilkapynas, Vilnius, 2009,

Paalksniu archeologijos paminklai, monografija, Vilnius 2011,

Paprūdžiai Žemaičiu karinio elito kapinynas, Vilnius 2014,

Romèniškojo laikotarpio emaliuoti dirbiniai Lietuvoje, Vilnius 2016,

cechują się olbrzymią erudycją i znawstwem poruszanej w nich problematyki, prezentowanej na najwyższym światowym poziomie naukowym. To samo należy powiedzieć o dziesiątkach artykułów, publikowanych zarówno w najlepszych europejskich czasopismach archeologicznych, jak i numizmatycznych, a także w wielu pracach zbiorowych. Wywarły one ogromy wpływ na rozwój środkowoeuropejskiej archeologii, w tym także na polskie studia tyczące pradziejów Bałtów.

Wileńskie uroczystości wręczenia Nagrody im. Józefa Kostrzewskiego objął swym patronatem i przewodniczył im Pan Jarosław Czubiński, Ambasador Nadzwyczajny i Pełnomocny RP w Republice Litewskiej. Wręczenia nagrody w obecności Jego Magnificencji Rektora Uniwersytetu Wileńskiego prof. dr. hab. Artūrasa Žukauskasa dokonał dr hab. Andrzej Michałowski, prof. UAM - wiceprezes Zarządu Głównego Stowarzyszenia Naukowego Archeologów Polskich, wraz z dr. hab. Jackiem Wierzbickim - wicedyrektorem Instytutu Archeologii UAM, i mgr Aliną Jaszewską - wiceprezesem Zarządu Głównego Stowarzyszenia Naukowego 


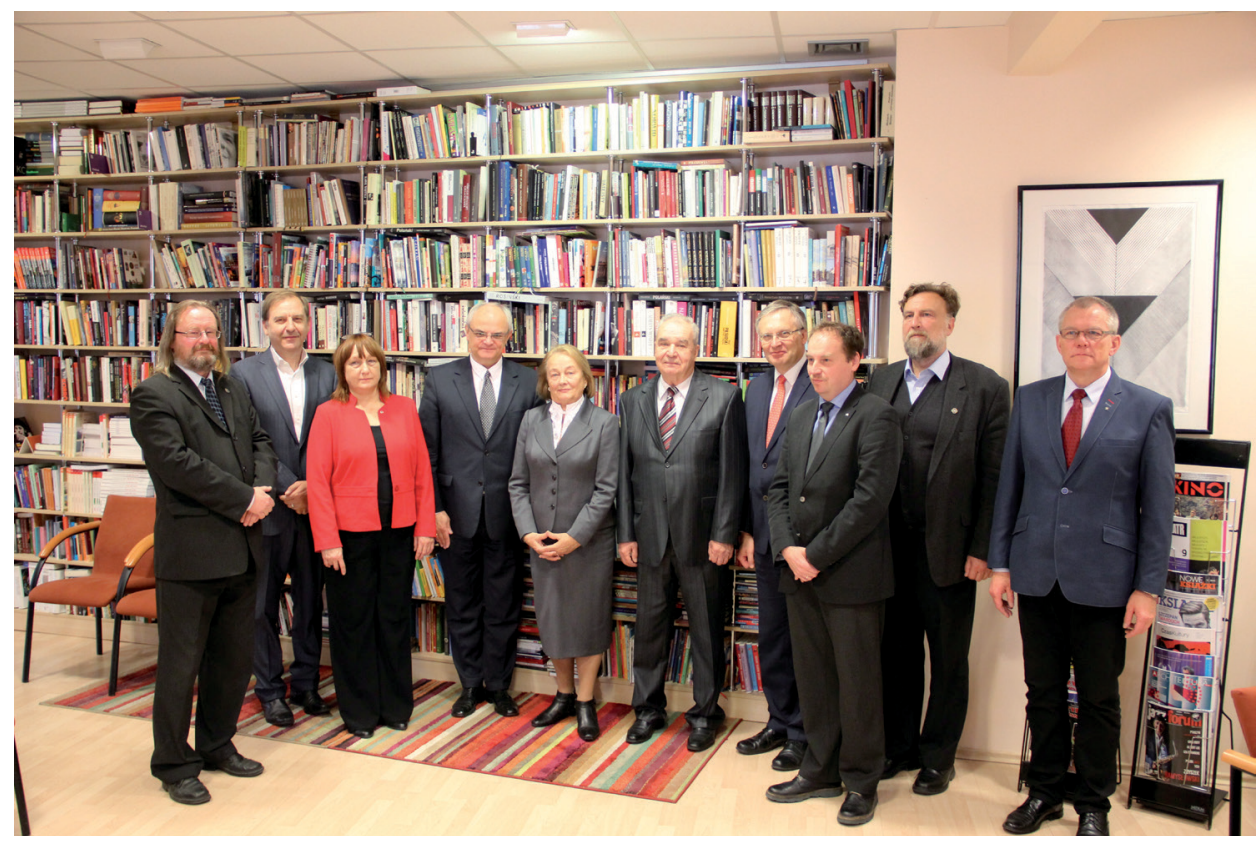

Fot. 2. Uczestnicy uroczystości wręczenia Nagrody im. Józefa Kostrzewskiego, Instytut Polski, Wilno 20 października 2016 roku (fot. Andrzej Kierulis)

Archeologów Polskich. W uroczystościach udział wzięli prof. dr hab. Rimantas Jankauskas, Prorektor ds. Badań Uniwersytetu Wileńskiego, prof. dr hab. Albinas Kuncevičius, Kierownik Katedry Archeologii Uniwersytetu Wileńskiego, oraz doc. dr Aleksiejus Luchtanas z Katedry Archeologii Uniwersytetu Wileńskiego (fot. 2). 